GUATEMALAN JOURNEY 


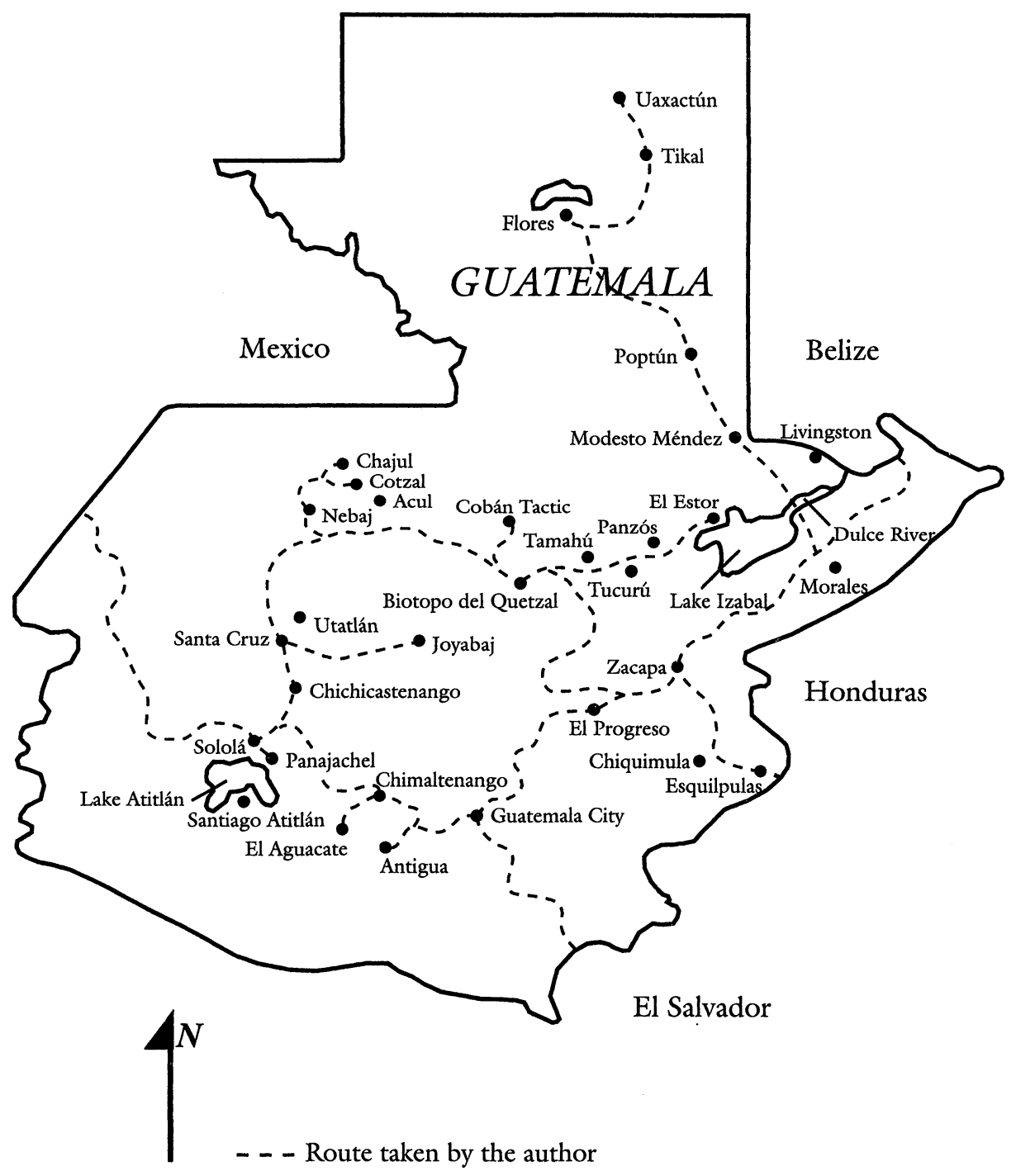




\section{GUATEMALAN JOURNEY}

by Stephen Connely Benz

4 UNIVERSITY OF TEXAS PRESS, AUSTIN 
Copyright (C) 1996 by the University of Texas Press

All rights reserved

Printed in the United States of America

Fourth paperback printing, 2006

Requests for permission to reproduce material from this work should be sent to:

Permissions

University of Texas Press

P.O. Box 7819

Austin, TX 78713-7819

http://utpress.utexas.edu/about/book-permissions

Library of Congress Cataloging-in-Publication Data

Benz, Stephen Connely, 1958-

Guatemalan journey / by Stephen Connely Benz.--ist ed. p. $\mathrm{cm}$.

Includes bibliographical references (p. | and index. ISBN-I 3: 978-0-292-70840-2 (pbk. : alk. paper) ISBN-IO: 0-292-70840-8

I. Guatemala-Description and travel. 2. GuatemalaHistory-I985- . 3. Americans-Guatemala. 4. Benz, Stephen Connely, I958- . I. Title.

FI464.3.B45 I996

$972.8 \mathrm{I}$ - de 20

95-III 38

ISBN 978-0-292-79268-5 (e-book)

ISBN 978-0-292-78299-0 (individual e-book) 
To my mother, who taught me the value of poetry. To my father, who taught me the value of reason. 
THIS PAGE INTENTIONALLY LEFT BLANK 